\title{
THE ANNUAL MEETING IN WASHINGTON
}

The sixty-seventh annual meeting of the American Mathematical Society was held at the Hotel Willard in Washington, D. C., on January 23-26, 1961. During the same week, with headquarters at the same hotel, there were meetings of the Association for Symbolic Logic, the Mathematical Association of America, and the Society for Industrial and Applied Mathematics. The attendance of 1,527, including 1,203 members of the Society is the largest in the records of this Society.

The thirty-fourth Josiah Willard Gibbs Lecture was presented by Professor J. J. Stoker of New York University. The high quality of the series was beautifully upheld. The title of the lecture was Problems in nonlinear elasticity. President Montgomery presided at the session, which took place at 8:00 P.M. on Tuesday, January 24, in the Grand Ballroom.

By invitation of the Committee to Select Hour Speakers for Annual and Summer Meetings, Professor Lars Hörmander of the University of Stockholm and the Institute for Advanced Study addressed the Society in the Grand Ballroom at 2:00 P.M. on Monday, January 23. The title of his address was On the range of differential operators. Dr. Vlastamil Ptak introduced the speaker.

By invitation of the same committee, Professor Helmut Wielandt of the University of Tübingen and the California Institute of Technology gave an address in the Grand Ballroom at 2:00 P.M. on Wednesday, January 25. His subject was On the structure of finite groups. The speaker was introduced by Professor Marshall Hall, Jr.

There were thirty-two sessions for contributed papers, at which a total of two hundred thirty-four papers were presented to the Society. The number of papers was somewhat larger than the number presented at the previous annual meeting and established a new record for the number of papers presented. The Society acknowledges with thanks the service of the following people in presiding over the sessions for contributed papers: Dr. Norman Bazley, Professors R. H. Bing, R. H. Cameron, V. F. Cowling, J. H. Curtiss, J. B. Diaz, Dr. R. D. Driver, Professors Carl Faith, D. J. Foulis, Murray Gerstenhaber, O. G. Harrold, Jr., Mr. Michael Goldberg, Professors Emil Grosswald, Erik Hemmingsen, J. E. Houle, Jr., S. B. Jackson, V. L. Klee, Jr., Jean E. LeBel, Dr. Benjamin Lepson, Professors L. F. McAuley, Josephine Mitchell, David Nelson, B. E. Rhoades, Walter Rudin, Anne E. Scheerer, Dr. Daniel Shanks, Dr. Oved Shisha, Pro- 
fessors M. F. Smiley, Andrew Sobczyk, Domina E. Spencer, ChoyTak Taam, and A. C. Zaanen.

As the meetings of this Society grow, it becomes increasingly necessary to use mechanical aids to the ear and eye in order that a large audience may follow all the details of a lecture. Of special note at this meeting was the fact that, with the cooperation of the manufacturer, the projection machine called the $\mathrm{Vu}-\mathrm{Graph}$ was available at every session. In addition, instruction was available about the use of the machine and materials could be procured for advance preparation of transparencies for projection during lectures. In the hands of a speaker who takes the pains to make careful preparation, the $\mathrm{Vu}$ Graph appears to be quite successful as an aid to the eye of the members of the audience.

Abstracts of the papers presented at the meeting appear in the Notices of the American Mathematical Society for December (issue no. 50) and succeeding issues. There were no papers presented by title except for the isolated instances of contributors who were unavoidably prevented from presenting in person a paper which had already been scheduled. This was the first meeting affected by the recently instituted plan of handling contributed papers for presentation by title through supplementary programs which are detached from any meeting of the Society.

The Annual Business Meeting of the Society was held in the Grand Ballroom at 2:00 P.M. on Thursday, January 26, 1961. Vice President Bohnenblust presided.

Appreciation was expressed to Professors John W. Brace and M. W. Oliphant for their contributions to the arrangements for the meetings.

Dr. W. Homer Turner, Executive Director of the United States Steel Foundation, made a short address to the business meeting and presented the Society with a check for five thousand dollars to assist in studying modes of communication between modern developments in mathematics and graduate students, and between the industrial mathematician and the academic mathematician.

The Secretary reported briefly on the affairs of the Society.

The Trustees of the Society met on the morning of Tuesday, January 26.

The Council of the Society met on the afternoon of Wednesday, January 25. After an intermission for dinner the meeting continued through the evening.

At the Council meeting, the Secretary announced the election of 
the following one hundred twenty-two persons to ordinary membership in the Society:

Mr. Oliver G. Aberth, Swarthmore College;

Mr. Achdat, Bandung Institute of Technology, Bandung, Java, Indonesia;

Mr. David J. Allen, Donell Farm, Bennington, Vermont;

Dr. Donald E. Amos, Sandia Corporation, Albuquerque, New Mexico;

Miss Kay A. Anderson, Analyst, Computer Sciences Corp., Inglewood, California;

Professor Kiyoshi Aoki, Niigata University, Niigata, Japan;

Mr. Lucio Artiaga, University of Saskatchewan;

Mr. George W. Batten, Jr., William Marsh Rice University;

Mr. Joseph Battle, University of Michigan;

Mr. James E. Benson, Fairleigh Dickinson University;

Mr. Richard W. Benson, Research Math., Pikewood Corp., Albuquerque, New Mexico;

Mr. Triloki N. Bhargava, Michigan State University;

Mr. Daniel G. Bobrow, Massachusetts Institute of Technology;

Mr. James R. Bower, University of Michigan;

Mr. Edwin H. Brackett, International Business Machines Corporation, Bethesda, Maryland;

Mrs. Olive S. Bowman, Bridgewater College;

Professor James R. Brown, University of Massachusetts;

Mr. Hernan R. Bravo Flores, Institute de Fisica y Mathmaticas, Chile;

Mr. Edward S. Brown, Jr., Defense Atomic Support Agency, Albuquerque, New Mexico;

Mr. Richard A. Byerly, The Association for Bank Audit Control and Operation, Clarendon Hills, Illinois;

Mr. Gaylord A. Capes, Westinghouse Electric Corp., Baltimore, Maryland;

Dr. Roderick G. Chisholm, St. Mary's College;

Mr. Donald H. Clanton, Oak Ridge National Laboratory, Oak Ridge, Tennessee;

Mr. William E. Christilles, St. Mary's College;

Mr. Richard L. Cline, International Business Machines Corp., New York, New York;

Mr. David B. Coghlan, Foote Mineral Company, Berwyn, Pennsylvania;

Sister Conrad, Central Catholic High School, Ft. Wayne, Indiana;

Mr. George T. Crocker, Auburn University;

Professor Ubiratan D'Ambrosio, University of São Paulo;

Professor Ludwig W. Danzer, University of Washington;

Mr. Gary A. Davis, Mt. Carmel College, Niagara Falls, Ontario, Canada;

Mr. James R. Dean, Technical Operations, Inc., Fort Monroe, Virginia;

Mr. Donald F. Dempsey, International Business Machines Corp., Dearborn, Michigan;

Mr. Louis E. De Noya, Oklahoma State University;

Professor Nicolae Dinculeanu, University of Bucarest, Bucarest, Roumania;

Dr. Andrew G. F. Dingwall, Radio Corporation of America, Harrison, New Jersey;

Miss Diane K. Downie, University of Idaho;

Mr. John R. Durbin, University of Kansas;

Dr. David B. A. Epstein, Princeton University;

Dr. Manus R. Foster, Socony Mobil Oil Co., Dallas, Texas;

Mr. Bernard L. Freese, Royal McBee Corp., Chicago, Illinois;

Mr. Robert B. Gardner, University of California; 
Mr. Francis J. Garvis, System Development Corp., Santa Monica, California;

Mr. Thomas M. Gill, Bethel College;

Mr. Samuel Gorenstein, System Development Corp., Paramus, New Jersey;

Professor Svend T. Gormsen, Virginia Polytechnic Institute;

Mr. George C. Graff, University of Illinois;

Mr. Frederick P. Greenleaf, Yale University;

Dr. George J. Habetler, General Electric Co., Schenectady, New York;

Dr. Asghar Hameed, Government College of Engineering and Technology, Pakistan;

Dr. Eldon R. Hansen, Lockheed Aircraft, Palo Alto, California;

Mr. Warren F. Haverkamp, Columbia Wax Co., Glendale, California;

Mr. Earl W. Hessee, Lockheed Aircraft Corp., Dawsonville, Georgia;

Mr. Kenneth L. Hillam, University of Colorado;

Mr. William W. Hokman, Virginia Polytechnic Institute;

Professor Kinya Honda, St. Paul's University, Tokyo, Japan;

Mr. Donald G. Hook, University of California;

Professor Paul H. Hutcheson, Middle Tennessee State College;

Mr. Douglas H. Hutchinson, Union Carbide Consumer Products Co., Cleveland, Ohio;

Professor John M. Irwin, New Mexico State University;

Mr. Robert C. Irwin, MITRE Corp., Bedford, Massachusetts;

Miss Joanne M. Jasper, Anna Maria College;

Mr. Robert E. D. Jones, Iowa State University;

Mr. William B. Jones, National Bureau of Standards, Boulder, Colorado;

Dr. Frank C. Karal, Jr., New York University;

Mr. Seymour Kass, University of Chicago;

Lt. Jerald C. Kindred, Air Force Department, Ft. Lawton, Washington;

Mr. Jerry P. King, University of Kentucky;

Mr. Kenneth R. Klopf, Shell Oil Co., Midland, Texas;

Mr. Bengt J. Kredell, ASEA, Vasteras, Sweden;

Mr. Isaac C. Lail, Army Department, Washington, D. C.;

Professor Lawrence H. N. Lee, University of Notre Dame;

Mr. Kenneth D. Lerche, Lehigh University;

Mr. Stanley M. Lukawecki, Auburn University;

Professor Gustave H. Lundberg, Vanderbilt University;

Reverend John J. MacDonnell, College of the Holy Cross;

Mr. Walter T. Mara, Monterey Peninsula College;

Dr. Eugene H. Nicholson, St. Louis, Missouri;

Mr. Torsten Norvig, University of Massachusetts;

Dr. Ernest L. Osborne, Washington, D. C.;

Mr. Jack L. Owens, Mene Grande Oil Co., Apartado 45, Barcelona, Venezuela;

Mrs. Frankie B. Patterson, Southern University;

Mr. Donald M. Peterson, Sr., Convair Corp., Ft. Worth, Texas;

Mr. Michael R. Pew, Electra Mfg., Independence, Kansas;

Mr. John A. Pfaltzgraff, University of Kentucky;

Mr. John T. Porter, Jr., Canateson Salvage, Moody, Texas;

Mf. Alfred G. Quade, Pure Oil Co., Chicago, Illinois;

Mr. Louis V. Quintas, City College, New York, New York;

Mr. Marlon C. Rayburn, Jr., Earlham College;

Mr. Clyde D. Rinker, Bendix Corp., Kansas City, Missouri;

Mr. Edwin H. Rogers, Carnegie Institute of Technology;

Dr. Bernard W. Roos, General Dynamics Corp., San Diego 12, California; 
Professor Paul T. Rygg, Montana State University;

Mr. William L. Salvatore, Classical High School, Providence, Rhode Island;

Miss Mary F. Saunders, Sanders Association, Inc., Nashua, New Hampshire;

Mr. Richard L. Schauer, University of Wisconsin;

Mr. Alvin L. Schreiber, Human Sciences Research, Inc., Arlington, Virginia;

Dr. Lorraine Schwartz, University of British Columbia, Vancouver;

Professor Robert E. Seal, Illinois Institute of Technology;

Mr. Freeman S. Sharp, Hyattsville, Maryland;

Dr. Isadore Silberman, Raytheon Corporation, Bedford, Massachusetts;

Mr. Michael S. Skaff, University of Illinois;

Mr. William T. Sledd, University of Kentucky;

Dr. Alan R. Smith, International Nickel Co. of Canada, Thompson, Manitoba;

Mrs. Dorothy P. Smith, New Mexico Highland University;

Mr. Robert P. Smith, Navy Department, Washington, D. C.;

Mr. Robert E. Spivack, University of South Carolina;

Brother Joseph W. Stander, University of Dayton:

Mr. Jeremy J. Stone, Stanford Research Institute;

Professor Charles F. Taylor, Maryville College;

Dr. Sean J. Tobin, University College, Galway, Ireland;

Professor Terry Triffet, Michigan State University;

Mr. Verlyn R. Unruh, System Development Corp., Santa Monica, California;

Professor Gerard J. Van Der Maas, University of Ottawa, Ottawa, Ontario;

Mr. John S. Warren, Boston Edison Co., Boston, Massachusetts;

Miss Martha F. Watson, University of Kentucky;

Professor James R. Webb, Louisiana State University;

Professor Arthur D. Wirshup, California State Polytechnic College;

Dr. N. Donald Ylvisaker, Columbia University;

Mr. Raymond A. Zachary, Jr., Texas Instruments Inc., Dallas, Texas;

Dr. James P. Zietlow, New Mexico Highland College.

It was reported that two hundred and ninety-six persons were elected to membership on nomination of institutional members as indicated:

University of Alberta:John W. Moon.

Andrews University: Mr. Theodore R. Hatcher.

Arizona State University: Professor Robert W. Sanders.

Auburn University: Mr. Porter G. Webster.

University of British Columbia: Miss Marguerite E. Barrett, Mr. Jay L. Delkin, Mr.

Alan R. Dobell, Mr. Gene B. Gale, Mr. William T. Iwata, Mr. Robert L. Johnston, Mr. Richard Lee, Mr. Donald J. Mallory, Mr. Frank C. May, Mr. Richard C. Willmott.

Brown University: Mr. Frederick J. Almgren, Jr., Mr. Paul Dormont, Mr. Joseph B. Geiser, Mr. Morton E. Gurtin, Dr. Robin J. Knops, Professor Allen C. Pipkin, Dr. Tryfan G. Rogers, Mr. Gordon B. Small, Jr., Mr. William F. Tyndall, Mr. Eric Varley, Mr. Michael Voichick.

California Institute of Technology: Mr. Stephen A. Andrea, Mr. Richard E. Balsam, Mr. Fletcher I. Gross, Mr. Alfred W. Hales, Mr. Donald E. Knuth, Mr. Louis A. Lopes, Jr., Mr. Jack W. Macki, Mr. Stanley A. Sawyer.

University of California, Berkeley: Mr. Bruce A. Bloomfield, Mr. Fraser A. Bonnell, Mr. Benson S. Brown, Miss Carole J. Colebob, Mr. Ernest T. Fickas, Mr. Haim 
Gaifman, Mr. Ronald L. Graham, Mr. Michel Jean, Mr. William L. Kent, Mr. Charles P. Luehr, Mr. George H. Orland, Mr. George S. Rinehart, Mr. Galen L. Seever, Mr. William H. Sills, Mr. Eleftherios C. Zachmanoglou.

University of California, Los Angeles: Mr. Lawrence P. Belluce, Mr. Stuart E. Black, Mr. Stanley P. Franklin, Mr. William M. Lambert, Jr., Mr. Ralph H. Wessner. Case Institute of Technology: Mr. Charles G. Cullen.

Catholic University of America: Mr. Gerald R. Andersen, Rev. John C. Friedell. University of Chicago: Mr. Robert B. Brown, Mr. Leif Kristensen, Mr. Tzee C. Kuo, Mr. Yung-Yung Lu, Miss Therese E. Raczynski, Mr. Mitchell H. Taibleson.

University of Colorado: Mr. John D. De Pree, Mr. David A. Shotwell.

Cornell University: Dr. Zbigniew Ciesielski, Dr. Caspar R. Curjel, Mr. Harold G. Diamond, Mr. Paul S. Green, Mr. Clifford T. Ireland, Mr. Alan McConnell, Mr. Stanley E. Mamangakis, Mr. Alfred B. Manaster, Mr. Irwin S. Pressman, Mr. John S. Rose, Mr. Chia-Hui Shih, Mr. Benjamin T. Smith, Dr. Samuel J. Taylor.

Duke University: Mr. David R. Anderson, Mr. Warren S. Edelstein, Mr. Dick L. George, Mr. David R. Hayes, Mr. Robert M. McConnel.

University of Florida: Mr. Billy R. Hare.

University of Georgia: Mr. Julio R. Bastida, Mr. Curtis P. Bell, Mr. Brittian J. Williams.

Harvard University: Mr. Edward B. Curtis, Mr. Jerry L. Fields, Mr. Bernard R. Kripke, Mr. Satish D. Shirali.

Illinois Institute of Technology: Mr. Eugene L. Allgower.

University of Illinois: Mr. Steven F. Bauman, Mr. Clinton R. Foulk, Mr. James J.. Gillian, Mr. Charles F. Koch, Mr. Charles G. Krueger, Mr. Gary K. Leaf, Mr. Eizo Nishiura, Mr. Surendra N. Patnaik, Dr. Chivukula R. Rao, Mr. Keith A. Rowe.

Institute for Advanced Study: Dr. James A. Green, Professor Tatsuo Homma, Professor Heinz Huber, Professor Jan W. Jaworowski, Dr. Mieo Nishi, Mr. Mikio Sato, Dr. Charles T. C. Wall.

Institute for Defense Analyses: Mr. Gerald J. Mitchell.

State University of Iowa: Mr. Orabi H. Alzoobaee, Mr. Norman Y. Luther, Mr. Joseph M. Martin, Mr. Donald V. Meyer.

Johns Hopkins University: Mr. George E. Lindamood, Mr. Peter H. Lord, Mr. Charles C. Pugh, Mr. Allan J. Silberger, Mr. Morris L. Thrower, Mr. J. Thomas Warfield, Miss Bernice Weinstein.

University of Kansas: Mr. Terrence J. Brown, Mr. William T. Covert, Mr. Eberhard G. P. Gerlach, Mr. J. Peter Johnson, Mr. Martin T. Lang, Mr. Paul W. Liebnitz, Mr. William D. McIntosh, Dr. Andrew Page, Mr. Raymond E. Pippert.

Lehigh University: Mr. Gerard E. Cozzolino, Mr. David K-s Hsieh.

McMaster University: Mr. Howard L. Jackson, Professor Derek J. Kenworthy.

University of Maryland: Mr. George R. Desi, Mr. Donald H. Flanders, Mr. Robert J. Gauntt, Mr. Svetozar Kurepa, Mr. Richard J. Weinacht, Professor Marvin Zelen.

Massachusetts Institute of Technology: Mr. Paul W. Abrahams, Mr. Howard E. Conner, Mr. Ramesh A. Gangolli, Mr. Joseph Hershenov, Mr. Louis Hodes, Mr. Gerald M. Leibowitz, Mr. David C. Luckham, Mr. Richard M. Moroney, Jr., Mr. William E. Ritter, Mr. Gabriel Stolzenberg, Mr. Norman R. Wagner, Mr. Israel J. Weinberg.

University of Miami: Mr. Charles R. Fitzpatrick, Mr. Jules B. Kaplan.

Michigan State University: Mr. John W. Baker, Mr. Mickey W. Dargitz, Mr. Donald L. Fisk, Mr. Jerome X. Goldschmidt, Mr. Robert L. Hemminger, Mr. David C. Kay. 
University of Michigan: Mr. George H. Andrews, Professor Robert J. Bridgman, Mr. John A. A. Kelingos, Mr. Patrick J. Ledden, Mr. Gerald E. Meike, Mr. Donald E. Sarason, Mr. George R. Sell, Professor Khyson Swong, Mr. Charles A. Trauth, Jr., Mr. Bertram J. Walsh.

University of Minnesota: Mr. Patrick R. Ahern, Mr. Jay P. Fillmore, Mr. C. J. Norman Fritz, Mr. Wayne W. Schmaedeke, Mr. James W. Yackel.

University of Missouri: Mr. William A. Kirk, Mr. Eugene F. Steiner, Mr. Paul E. Waltman.

University of Nebraska: Mr. Jerrold W. Bebernes.

University of New Hampshire: Mr. Robert E. O'Malley, Jr.

New Mexico State University: Mr. William E. Walden.

New York University: Mr. Yung M. Chen, Mr. Djairo G. De Figueiredo, Mr. George W. Logemann, Professor Sigeru Mizohata, Mr. Kennard W. Reed, Jr., Mr. Alan D. Solomon, Mr. George R. Stell, Mr. Robert E. L. Turner.

State University of New York: Miss Patricia L. Bihr.

University of North Carolina: Mr. Anil K. Bose, Mrs. Rebecca S. Cox, Mr. John R. Dowdle, Mr. Paul M. LeVasseur, Mr. Robert E. Spencer, Mr. Clifton T. Whyburn.

Ohio State University: Mr. Robin W. Chaney, Mr. Robert L. McFarland, Miss Joan E. Smith.

University of Oklahoma: Mr. Forrest R. Miller, Jr., Mr. David R. Proctor, Mr. Eugene E. Slaughter, Jr.

Oklahoma State University: Mr. David R. Cecil, Professor Glen A. Haddock.

University of Oregon: Mr. Robert M. Fesq, Mr. Lowell A. Hinrichs, Mr. Raymond E. Smithson, Mr. Charles L. Vanden Eynden.

Pennsylvania State University: Mr. Joseph A. Cima, Mr. Alan S. Cover, Mr. Barry F. Kramer.

Princeton University: Mr. Christopher Anagnostakis, Mr. R. Gordon Barker, Mr. Lutz Bungart, Mr. William G. Faris, Mr. John A. Hartigan, Mr. Robert C. Hartshorne, Mr. Peter J. Kahn, Mr. J. Peter May, Mr. Stephen Scheinberg, Mr. John J. Simon, Mr. Michael D. Spivak, Mr. William A. Veech, Mr. Robert Wells, Mr. Seth I. Zimmerman.

Purdue University: Mr. John R. Alexander, Jr., Mr. Robert D. Bechtel, Mr. Richard E. Hughes, Mr. Kenneth R. King, Mr. Frank A. Smith, Mr. Joel A. Smoller, Mr. John R. Sorenson, Mr. Jack R. Stodghill.

Rice University: Mr. Norman A. Shenk, II.

Rutgers, The State University: Mr. Michael W. Lodato, Mr. Chung L. Wang, Mr. Israel Zuckerman.

University of Southern California: Professor Gunter Ewald, Mr. Arthur S. Leslie, Miss Emily B. A. McCormick, Mr. Guillermo Restrepo, Professor Koichi Yamamoto.

South Dakota School of Mines and Technology: Mr. Martin J. Marsden.

Stanford University: Mrs. Patricia W. Beckman, Mr. William H. Berry, Mr. Bradley Efron, Mr. Martin Engert, Mr. Henry E. Pettis, Mr. Louis A. Fine, Mr. Jon D. Hopper, Mr. Leroy V. Junker, Mr. Franklin Lowenthal, Mr. Joseph Novello, Mr. James M. Ortega, Mr. Lawrence M. Perko, Mr. Jon E. Petersen, Mr. William H. Row, Jr., Miss Margaret E. Salmon, Mr. Dale W. Thoe, Mr. Arthur W. J. Ullman, Mr. Robert E. Wellck.

Stephen F. Austin State College: Mr. R. G. Dean.

Syracuse University: Mr. Stanley I. Mack.

University of Texas: Mr. William C. Bean, Mr. Saul I. Drobnies, Mr. Donald J. Hansen, Miss Blanche J. Monger, Mr. Douglas R. Stocks, Jr., Mr. Dale E. Walston. 
University of Toronto: Mr. Edward J. Barbeau, Mr. Alan S. Deakin, Mr. Andrew J. Korsak, Mr. Donald R. Miller, Professor Kunio Murasugi.

Tulane University: Mr. Sigmund N. Hudson, Mr. Harold D. Kahn, Mr. Harry T. Mathews, Mr. David E. Penney, Mr. Walter J. Schneider.

Vassar College: Miss Sandra A. Hayes.

University of Virginia: Mr. Alvin B. Owens, Mr. Thomas W. Page, Professor George K. Williams.

Washington University: Mr. Richard A. Hunt, Mr. Arthur E. Obrock, Mr. Bobba S. Reddy.

Washington State University: Mr. William S. Eberly.

Wayne State University: Mr. John C. Cantwell, Mr. Ronald J. Knill, Mr. John O. Riedl.

College of William and Mary in Norfolk: Miss Ellen Stone.

Yale University: Mr. Laurence R. Alvarez, Mr. John D. Ferguson, Mr. John N.

Frampton, Mr. Claude C. Thompson, Mr. Hoyt D. Warner.

The Secretary announced that the following had been admitted to the Society in accordance with reciprocity agreements with various mathematical organizations: Wiskundig Genootschap te Amsterdam: Mr. Jan R. Strooker, Professor Jacobus H. Van Lint; Australian Mathematical Society: Dr. James H. Michael; Austrian Mathematical Society: Professor Wolfgang Schmidt; Dansk Matematisk Forening: Mr. Palle F. Schmidt; Deutsche Mathematiker Vereinigung: Professor Friedemann W. Stallman, Dr. Joseph F. Weier; Société Mathématique de France: Mr. Dean M. Abadie; Indian Mathematical Society: Professor Ram Behari, Professor Phatik C. Chatterjee, Dr. Mohindar S. Cheema, Professor V. Ganapathy Iyer, Professor V. Sankriti Krishnan, Professor Bangalore S. Madhavarao, Professor Ratan S. Mishra; Mathematical Society of Japan: Professor Eizi Inaba, Professor Seizo Ito, Professor Hitoshi Iyoi, Professor Koiti Konda, Professor Tadao Kubo, Professor Katsuhiko Masuda, Professor Isamu Mogi, Professor Osamu Nagai, Professor Toshio Nonaka, Professor Yuzo Utumi, Professor Hidekazu Wada, Professor Kaneo Yamada, Mr. Yukihiro Kodama, Mr. Satio Okada; London Mathematical Society: Dr. Robin O. Gandy; Dr. Mary R. Rees; Polskie Towarzystwo Matematiyczne: Professor Marek Fisz; Suomen Matemaattinen Yhdistys: Dr. Jussi I. Vaisala; Svenska Matematikersamfundet: Mr. Sture Danielson, Mr. J. Torgny Domar, Mr. Matts R. Essen; Unione Matematica Italiana: Dr. Ferrante Pierantoni.

It was reported that J. M. Thomas represented the Society at the Fiftieth Anniversary Celebration of North Carolina College; Edward S. Hammond represented the Society at the Inauguration of Robert Edward Lee Strider II of Colby College; and Robert A. Rosenbaum represented the Society at the Silver Convocation of the University of Connecticut honoring President Albert N. Jorgensen. 
The following committee appointments of the President were reported: to the Committee on Applied Mathematics: G. E. Forsythe and V. Bargmann; to the Committee to Select Speakers for Summer and Annual Meetings: Saunders MacLane; to the Committee to Select Speakers for Eastern Meetings: W. L. Chow; to the Committee to Select Speakers for Western Meetings: M. Heins; to the Committee to Select Speakers for Far Western Meetings: Ernst Straus; to the Committee to Select Speakers for Southeast Meetings: Kirk Fort; to the Visiting Lectureship Committee: J. L. Kelley; to the Committee to Select Four Members of the Council to run for the Executive Committee: Garrett Birkhoff, Edwin Hewitt, and F. Burton Jones; as tellers for the 1960 election: P. C. Curtis and R. J. Blattner; Committee on the Cole Prize in Number Theory to be awarded in January 1962: D. H. Lehmer, Chairman, Serge Lang and S. Chowla; to the Joint Committee on the Doctor of Arts Degree: E. E. Moise, Chairman, M. M. Day, Paul Halmos, and A. D. Wallace; to the Invitations Committee for the Summer Institute on "Applications of Functional Analysis in 1961," P. D. Lax, Chairman, R. S. Phillips and Henry Helson; to the Committee to Nominate Officers and Members of the Council for the 1961 election: E. E. Floyd, Chairman, P. R. Halmos, Edwin Hewitt, W. T. Martin and Hans Samelson; to the Invitation Committee for a Symposium on Mathematical Problems in the Biological Sciences in April 1961: S. M. Ulam, Chairman, A. Bartholomay, R. Bellman, J. Jacquez, T. T. Puck, and Claude Shannon.

The Secretary reported that the following have accepted invitations to deliver Hour Addresses before the Society: Gail S. Young, November, 1960, Vanderbilt University; Graham Higman, November, 1960, Northwestern University; Helmut Wielandt and Lars Hörmander at the Annual Meeting, 1961; Henry Helson, November, 1961, Santa Barbara, California; R. A. Beaumont, Far Western Meeting in Spring, 1962; Israel N. Herstein and James A. Jenkins, April, 1961, Chicago Meeting.

Upon the recommendation of the Committee on Translations, the Council recommended to the Trustees that a new publication series devoted to the translation of papers in probability and statistics be established. The Council also recommended that starting January 1 , 1961, the Chinese Journal "ACTA MATHEMATICA SINICA" be translated in toto and published by the Society.

The Council, acting upon the recommendation of the Joint Committee on the Doctor of Arts Degree under the Chairmanship of Professor E. E. Moise, voted to support the action of the Board of Governors of the Mathematical Association of America in their rec- 
ommendation that the degree of Doctor of Arts be established, in mathematics, at most of the universities which are qualified to grant the Ph.D.

The Council approved a recommendation of the Transactions Editorial Committee that its membership be increased to five and elected Professor Michel Loève to fill the three year term created by the Council's action.

The Council voted to elect Professor L. J. Paige as Acting Secretary of the Society for the period February 1, 1961, to September 16, 1961, in the absence of Professor John W. Green.

Lowell J. Paige, Acting Secretary

Everett Pitcher, Associate Secretary

J. W. GReEn, Secretary 